\title{
Papillary Mucinous Cystadenoma
}

National Cancer Institute

\section{Source}

National Cancer Institute. Papillary Mucinous Cystadenoma. NCI Thesaurus. Code C4184.

A usually benign and less often low malignant potential cystic epithelial neoplasm composed of cells which contain intracytoplasmic mucin. It is characterized by the presence of papillary structures. 